\title{
Dynamics of Small-Scale Topographic Heterogeneity in European Sandy Salt Marshes
}

\author{
Kelly Elschot and Jan P. Bakker* \\ Conservation Ecology Group, University of Groningen. PO Box 11103, 9700CC Groningen, The Netherlands; \\ kellyelschot1@gmail.com \\ * Correspondence: j.p.bakker@rug.nl; Tel.: +31-50-3636133 \\ Academic Editor: Gerben Ruessink
}

Received: 7 December 2015; Accepted: 24 February 2016; Published: 3 March 2016

\begin{abstract}
Heterogeneity can boost biodiversity, as well as increase the resilience of an ecosystem to changing environmental conditions; therefore, it is important to understand how topographic heterogeneity in ecosystems is formed. Sandy tidal marshes have a repetitive pattern of higher elevated hummocks surrounded by lower elevated depressions, representing topographic heterogeneity at the scale of a few square meters. The aims of this study were to determine when this topographic heterogeneity forms, how it is structured, and whether it persists during marsh development. The soil topography of marshes consists of coarse-grained sediment formed before marsh vegetation development, with an overlaying fine-grained sediment layer formed after initial marsh development. To gain insight into the formation of topographic heterogeneity, we studied the underlying soil topography of four European sandy marshes, where topographic heterogeneity at a scale of a few square meters was present. The differences in elevation between hummocks and depressions can either be caused by heterogeneity in the coarse-grained sediment or by heterogeneity in the top layer containing the fine-grained sediment. Our results showed that the largest percentage of elevational differences between hummocks and depressions could be attributed to heterogeneity in the underlying coarse-grained substratum. Therefore, we conclude that the patterns in all four marshes were primarily formed before marsh development, before fine-grained sediment was deposited on top of the coarse-grained sediment. However, a smaller percentage of the elevational difference between hummocks and depressions can also be explained by the presence of thicker fine-grained sediment layers on top of hummocks compared with depressions. This implies that marsh accretion rates were higher on hummocks compared with depressions. However, this result was limited to very early stages of marsh development, as marsh accretion rates estimated on marshes ranging between 15- and 120-years-old showed that depressions actually accreted sediments at a significantly faster rate than hummocks. Eventually, the patterns of heterogeneity stabilized and we found similar marsh accretion rates on hummocks and in depressions in the 120-year-old marsh, which resulted in the persistency of these topographic patterns.
\end{abstract}

Keywords: accretion; coarse-grained sediment; depression; fine-grained sediment; hummock

\section{Introduction}

Heterogeneity can have large impacts on the functioning of ecosystems [1], boosting biodiversity $[2,3]$, as well as increasing the resilience of an ecosystem and its associated species to changing environmental conditions [4,5]. When spatial heterogeneity is present within an ecosystem, it can result in more niches, which increases the number of plant species able to co-exist on a smaller spatial scale [2,4]. As different plant species will respond differently to rapid changes in environmental conditions, this will increase the resilience of an ecosystem to cope with these rapid changes [1]. Understanding the formation and persistence of spatial heterogeneity, therefore, is important now 
since climate change is threatening many ecosystems on a global scale and many species are at risk of becoming extinct [6]. This is especially true for coastal ecosystems, which are particularly vulnerable to the effects of climate change and resulting enhanced sea-level rise $[7,8]$. In this study, we focused on the formation, structure, and persistence of small-scale topographic heterogeneity in sandy marshes.

Salt-marsh development is initiated when pioneer vegetation establishes on a bare coarse-grained intertidal flat or sand bank, and fine-grained sediment (silt) deposition starts to accumulate [9]. As a consequence, the soil profile of sandy minerogenic marshes generally consists of coarse-grained sediment covered with a thin layer of fine-grained sediment [9]. Vegetation has been shown to increase the sediment deposition rate and reduce the erosion rate by stabilizing the soil [10-12]. Fine-grained sediments deposited by tides and local vegetation determine the later morphology of the marsh platform [13-15].

Sandy marshes in Europe have fine patterns at the scale of a few square meters in marsh morphology [16-19]. These patterns consist of a repetitive pattern of higher elevated, sandy hummocks covered with a thin fine-grained sediment layer surrounded by lower elevated depressions. The hummocks range between a few centimeters to a few meters in diameter, and elevational differences between hummocks and depressions can be up to $30 \mathrm{~cm}$. The plant community of hummocks and depressions significantly differ in composition. In Britanny, hummock formation was shown to start with the perennial Salicornia radicans, followed by Puccinellia maritima and Atriplex portulacoides, whereas the annual Salicornia herbacea established in depressions. The hummocks appeared to be gradually coalesced over time, resulting eventually in more level ground [20]. In Wales, lateral extension of the pioneer species Puccinellia maritima, and later other species, filled the depressions between hummocks leading to hummock coalescence. Eventually, the general surface of the marsh became more even due to reduced sedimentation rates on the higher parts [21]. Both studies suggest these patterns are transitional. In the Netherlands, however, patterns of hummocks and depressions on the 100 year old salt marsh of Schiermonnikoog were observed (pers. observation). The origin and persistence of these patterns are still unclear, as is whether they emerge from similar processes in different marshes.

To gain more insight into the formation, structure, and persistence of these small-scale topographic patterns, we conducted a study on four different sandy marshes in Europe. We reasoned that topographic patterns can arise from heterogeneity of the underlying coarse-grained substratum and/or differences in the local fine-grained sediment layer. Two contrasting hypotheses were tested: 1) the patterns are formed in the pioneer stage before marshes develop, or 2) the patterns are formed after marsh development. To test these two hypotheses, we compared the vertical soil profile underlying heterogeneous marshes, with hummocks and depressions, to those underlying homogeneous marshes, with no clear hummocks and depressions. Additionally, we measured marsh accretion rates of hummocks and depressions at marshes between 15 and 120 years of age.

\section{Methods}

\subsection{Study Sites}

We included four sandy marshes located in Northwestern Europe (Figure 1) that featured hummocks and depressions: the Cefni Marsh (United Kingdom), Schiermonnikoog (The Netherlands), Terschelling (The Netherlands), and Skallingen (Denmark). Three different types of marshes were represented in that the Cefni marsh is located within the Cefni Bay, Schiermonnikoog, and Terschelling are back-barrier marshes located on islands, and Skallingen is on a peninsula. The soil profile on these sandy marshes consisted of a fine-grained, silty sediment layer on top of a coarse-grained, sandy sediment deposited before the marshes started to form [9]. The transition between these layers was very distinct [22] and allowed us to measure the thickness of the fine-grained sediment layer with great precision (up to a few millimeters). 


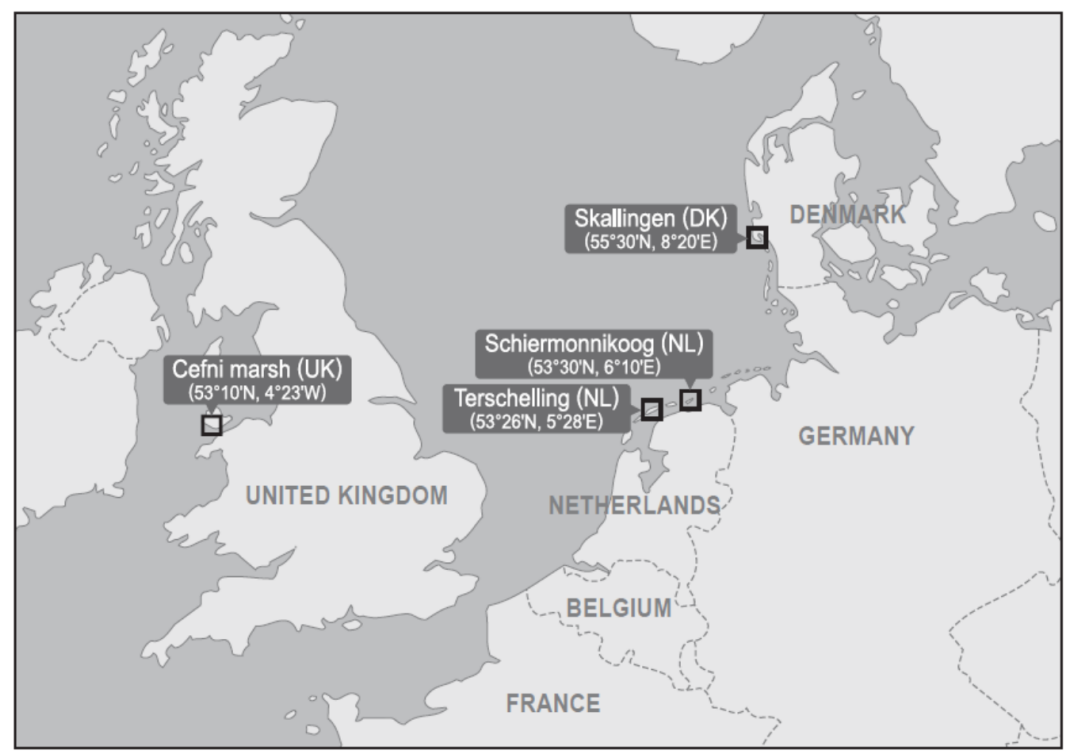

Figure 1. Field sites included in this study.

In Cefni Bay, salt-marsh development has only started since the 1960s [23]. Due to continuous expansion of the southern coast northward into the bay, a large pioneer zone is present in front of the Cefni marsh. In this pioneer zone, we studied higher elevated hummocks covered by Puccinellia maritima that were present on the otherwise bare intertidal flats. On Schiermonnikoog we studied the patterns along a natural chronosequence. A previous study used aerial photographs and topographic maps to identify marshes of different ages that were present adjacent to each other on Schiermonnikoog [9]. This chronosequence arose due to changing sea currents that have caused the island to grow eastwards, resulting in continuous new formation of dunes on the north side of the island and marshes behind them. Marsh age was determined from the first establishment of marsh vegetation identified from a time-series of maps and aerial photographs (for further detail see also [9]). We included marsh sites of approximately 15, 30, 45, 55, and 120 years of age in 2010. Marsh sites in this study were not grazed by livestock.

\subsection{Patterns in Soil Morphology}

To gain insight into the soil morphology and determine whether the underlying coarse-grained sediment differed between heterogeneous and homogeneous marshes (marsh without small-scale topographic heterogeneity), we sampled transects ranging from $70 \mathrm{~m}$ to $300 \mathrm{~m}$ in length. Both at the Cefni marsh (August 2011) and on Schiermonnikoog (May 2009), transects were measured starting on the marsh platform (underneath a dune on Schiermonnikoog and from the edge of a creek on the Cefni marsh) towards the intertidal flats. Along the marsh surface, we estimated the surface elevation and fine-grained sediment layer thickness every $0.5 \mathrm{~m}$. We increased the number of measurements to every $0.25 \mathrm{~m}$ near transitions between hummocks and depressions to prevent missing any hummocks or depressions. The surface elevation was measured using an optical levelling instrument (Spectra Precision ${ }^{\circledR}$ Laser LL500 and Spectra Precision ${ }^{\circledR}$ Laser HR500 laser receiver by Trimble, Dayton, OH, USA) with an accuracy of $\sim 5 \mathrm{~mm}$. The fine-grained sediment layer thickness was measured using a small soil corer (diameter $=10 \mathrm{~mm}$ ) with an accuracy of $5 \mathrm{~mm}$. The corer was inserted vertically into the marsh platform and extracted, after which we could measure the thickness of the fine-grained sediment layer based on the soil profile exposed in the corner.

At the Cefni marsh, we compared two transects in the heterogeneous marsh (transect 1 and 2) with one transect in the homogeneous marsh (transect 3). All transects were located approximately $200 \mathrm{~m}$ apart from each other and covered both the marsh zone and part of the pioneer zone that is located 
in front of the marsh. On Schiermonnikoog, we compared one transect in the heterogeneous marsh with one transect in the homogeneous marsh. Both transects were measured on the 30 year-old-marsh, approximately $100 \mathrm{~m}$ apart from each other. Due to time constraints we could not measure similar transects on Skallingen or Terschelling.

\subsection{Coarse-Grained vs. Fine-Grained Heterogeneity in Four Sandy Marshes}

To study the generality of the topographic patterns (hummocks and depressions), we compared the soil topography of four European tidal marshes. We included the Cefni marsh (August 2011), Schiermonnikoog (May 2009), Terschelling (October 2010), and Skallingen (September 2009). We took pair-wise measurements of the marsh elevation on hummocks and in neighboring depressions with a distance of $\sim 0.5 \mathrm{~m}$ between them. We decided upon a distance of $\sim 0.5 \mathrm{~m}$ to be consistent in our methodology, and close enough to prevent site-specific differences within a paired sample. The sample sizes, tidal ranges, and dominant plant species are given in Table 1 . We selected elevated hummocks, which ranged from a few centimeters up to a few meters in diameter. For each of these paired measurements, we estimated surface elevation according to Mean High Tide (MHT), measured fine-grained sediment layer thickness with a small corer (10 $\mathrm{mm}$ in diameter, similarly as mentioned in the previous section), and recorded the three most dominant plant species. The fine-grained sediment layer thickness was subtracted from the measured marsh elevation to determine the elevation of the underlying coarse-grained sediment. At the Cefni marsh, we selected hummocks and neighboring depressions alongside the three transects mentioned in the previous section, covering a large marsh surface area ( $\sim 6 \mathrm{ha})$. The samples were taken in the pioneer zone, as well as the marsh zone. Vegetated hummocks located on bare intertidal flats, the flats that did not yet have a fine-grained sediment layer were referred to as in the pioneer zone. When vegetated hummocks were surrounded by vegetated depressions that had a fine-grained sediment layer, then we referred to them as in the marsh zone. On Schiermonnikoog, we included five marsh sites of different ages: 15, 30, 45,55 , and 120 year-old marshes, which prevents any age bias. All samples of the different marsh ages estimated on Schiermonnikoog were pooled together for further analyses. On Terschelling and Skallingen, we selected hummocks and neighboring depressions over a large marsh surface area of a few hectares.

Table 1. Characteristics and sampling effort at marsh sites.

\begin{tabular}{|c|c|c|c|c|c|}
\hline & $\mathbf{n}$ & Tidal Range (m) & $\begin{array}{l}\text { Most Dominant Plant } \\
\text { Species }\end{array}$ & $\begin{array}{l}\text { 2nd Most Dominant } \\
\text { Plant Species }\end{array}$ & $\begin{array}{l}\text { 3rd Most Dominant } \\
\text { Plant Species }\end{array}$ \\
\hline \multicolumn{6}{|l|}{ Hummocks } \\
\hline Cefni marsh & & $4.7^{*}$ & & & \\
\hline Pioneer zone & 95 & & Puccinellia maritima & Bare soil & Armeria maritima \\
\hline Marsh zone & 60 & & Bare soil & Armeria maritima & Festuca rubra \\
\hline Terschelling & 40 & 2 & Festuca rubra & Puccinellia maritima & \\
\hline Skallingen & 41 & 1.3 & Festuca rubra & Artiplex portulacoides & \\
\hline Schiermonnikoog & & 2.3 & & & \\
\hline 15 year-old marsh & 55 & & Limonium vulgare & Festuca rubra & Atriplex portulacoides \\
\hline 30 year-old marsh & 55 & & Festuca rubra & & \\
\hline 45 year-old marsh & 62 & & Festuca rubra & Artemisia maritima & Puccinellia maritima \\
\hline 55 year-old marsh & 38 & & Festuca rubra & Artemisia maritima & Elytrigia atherica \\
\hline 120 year-old marsh & 66 & & Festuca rubra & Puccinellia maritima & Artemisia maritima \\
\hline \multicolumn{6}{|l|}{ Depressions } \\
\hline Cefni marsh & & $4.7^{*}$ & & & \\
\hline Pioneer zone & 95 & & Bare soil & & \\
\hline Marsh zone & 60 & & Bare soil & Puccinellia maritima & Plantago maritima \\
\hline Terschelling & 40 & 2 & Limonium vulgare & Atriplex portulacoides & Aster tripolium \\
\hline Skallingen & 41 & 1.3 & Atriplex poartulacoides & & \\
\hline Schiermonnikoog & & 2.3 & & & \\
\hline 15 year-old marsh & 55 & & Bare soil & Limonium vulgare & Atriplex portulacoides \\
\hline 30 year-old marsh & 55 & & Limonium vulgare & Atriplex portulacoides & Bare soil \\
\hline 45 year-old marsh & 62 & & Limonium vulgare & Salicornia europaea & Atriplex portulacoides \\
\hline 55 year-old marsh & 38 & & Limonium vulgare & Atriplex portulacoides & Festuca rubra \\
\hline 120 year-old marsh & 66 & & Atriplex poartulacoides & Festuca rubra & Salicornia europaea \\
\hline
\end{tabular}




\subsection{Marsh Accretion Rates during Marsh Development}

To compare long-term marsh accretion rates between hummocks and depressions, sediment and erosion bars (SEBs, see also [24,25]) were placed along the natural chronosequence on Schiermonnikoog in 2001 at the 15, 30, 45, 55, and 120 year-old marshes. Each SEB consisted of two poles that were placed $2 \mathrm{~m}$ apart on the marsh platform, with one pole located on top of a hummock and one pole located within a depression. This set-up was duplicated three times per site. For stabilization, each pole was inserted at least $1.0 \mathrm{~m}$ into the underlying coarse-grained sediment. An aluminum bar with 17 holes $0.1 \mathrm{~m}$ apart along the entire length of the bar was placed on top of the two poles during measurement. We estimated the elevation of the marsh platform by inserting a small pin vertically through each hole until it touched the marsh platform and measured the length of the pin left above the aluminum bar. Between 2001 and 2011, we estimated marsh accretion rates yearly. Due to unrealistic accretion rates of $\sim 10 \mathrm{~cm}$ found in the 2003 data, we removed all measurements taken in 2003 from further analyses.

\subsection{Data Analysis}

To analyze the SEB data, we visually assigned each individual measurement in the field to hummock, depression, or transition state, i.e., located on the edge of a hummock. In the following analyses, we only included the measurements taken from hummocks and depressions, omitting data from transition states. An average annual marsh accretion rate was first calculated for each SEB individually by averaging over the 17 holes and over all the years measured. Ultimately, this resulted in three marsh accretion rates ( $\mathrm{cm} \cdot$ year $^{-1}$ ) per treatment (hummock or depression) for each marsh site. Thereafter, we tested for any significant effects between treatments using an ANOVA with marsh age and treatment (hummock or depression) as categorical predictors.

\section{Results}

When comparing the heterogeneous and homogeneous marshes in Cefni and Schiermonnikoog, all transects showed that the morphology of the marsh platform was similar to the elevational heterogeneity found in the underlying coarse-grained sediment (Figure 2). Transects measured in heterogeneous marsh sites with hummocks and depressions present had the same elevational heterogeneity in the underlying coarse-grained sediment (Figure 2a, first transect, and Figure $2 \mathrm{~b}$, first and second transect). Furthermore, in marsh sites that were relatively homogeneous in marsh morphology (Figure 2a, second transect, and Figure 2b, third transect), we found a similarly homogeneous elevation in the underlying coarse-grained sediment.

When comparing all four marshes, elevational differences between hummocks and depressions ranged from $6.9 \mathrm{~cm}$ on Terschelling to $12.5 \mathrm{~cm}$ at the Cefni marsh (Figure 3). The largest percentage of the elevational difference was caused by heterogeneity in the underlying coarse-grained sediment, ranging between $55 \%$ on Schiermonnikoog to $92 \%$ at the Cefni marsh. A smaller percentage of the elevational differences between hummocks and depressions could also explained by the fine-grained sediment layer (Figure 3). On all four marshes, thicker fine-grained sediment layers were found on top of hummocks compared to depressions. At one extreme, hummocks on Schiermonnikoog had a $3.4 \mathrm{~cm}$ thicker fine-grained sediment layer than depressions, whereas this difference was limited to only $1.0 \mathrm{~cm}$ at the Cefni marsh. At the Cefni marsh, up to $11.5 \mathrm{~cm}$ of the elevational difference was caused by the underlying coarse-grained sediment. Consistently at all four marshes, the hummocks consisted of higher elevated sand bodies and this original topography was conserved under a fine-grained sediment layer. The marsh accretion rates estimated along the natural chronosequence on Schiermonnikoog (Figure 4) differed significantly between hummocks and depressions, and changed with marsh age. Accretion rates decreased as marshes aged $\left(F_{4,24}=7.56, p<0.001\right)$ and were significantly higher in depressions compared to hummocks $\left(F_{1,24}=10.14, p<0.01\right)$. We found no significant interaction effect between marsh age and treatment (hummocks or depressions). 


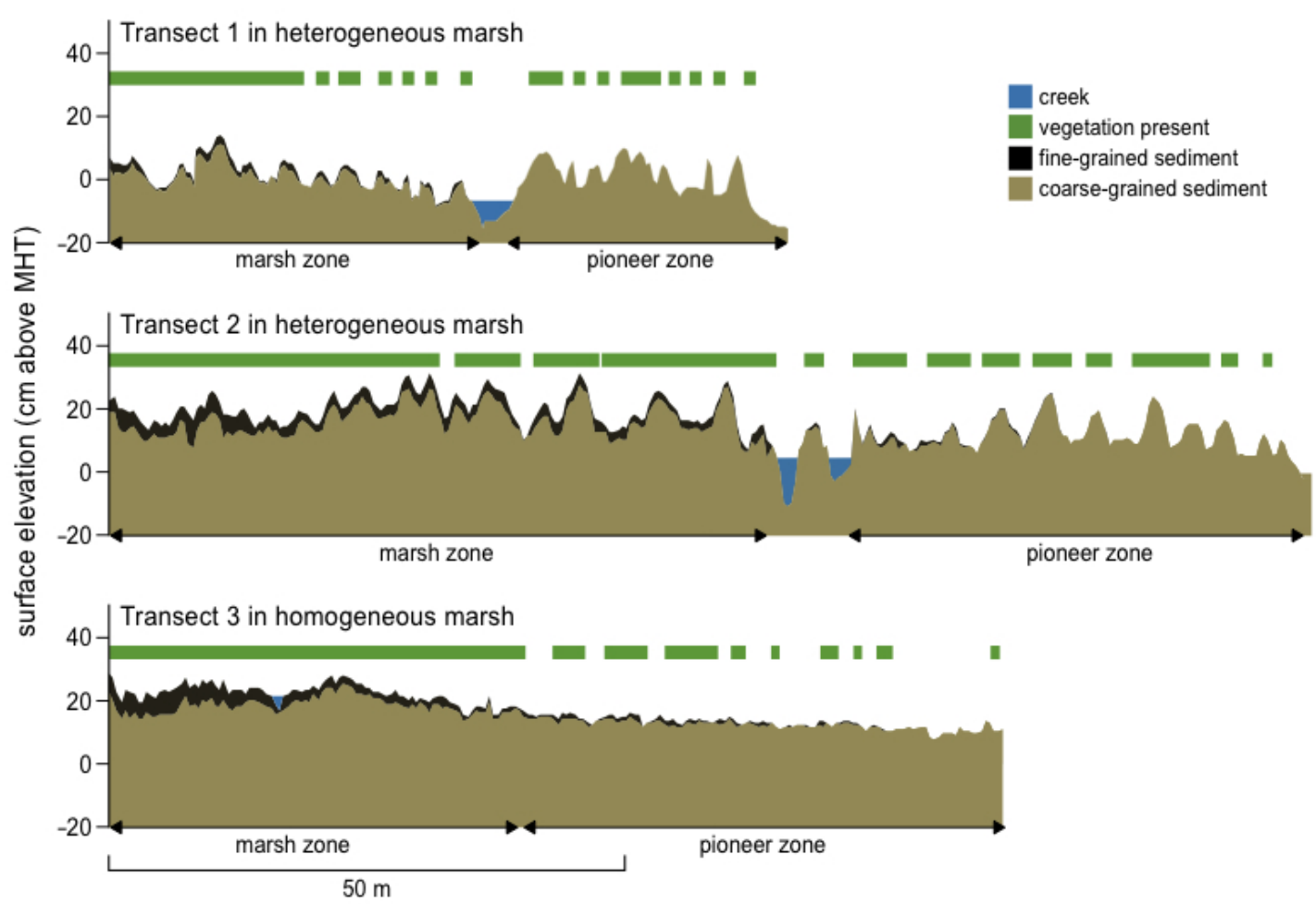

B

Two transects measured on Schiermonnikoog (NL)

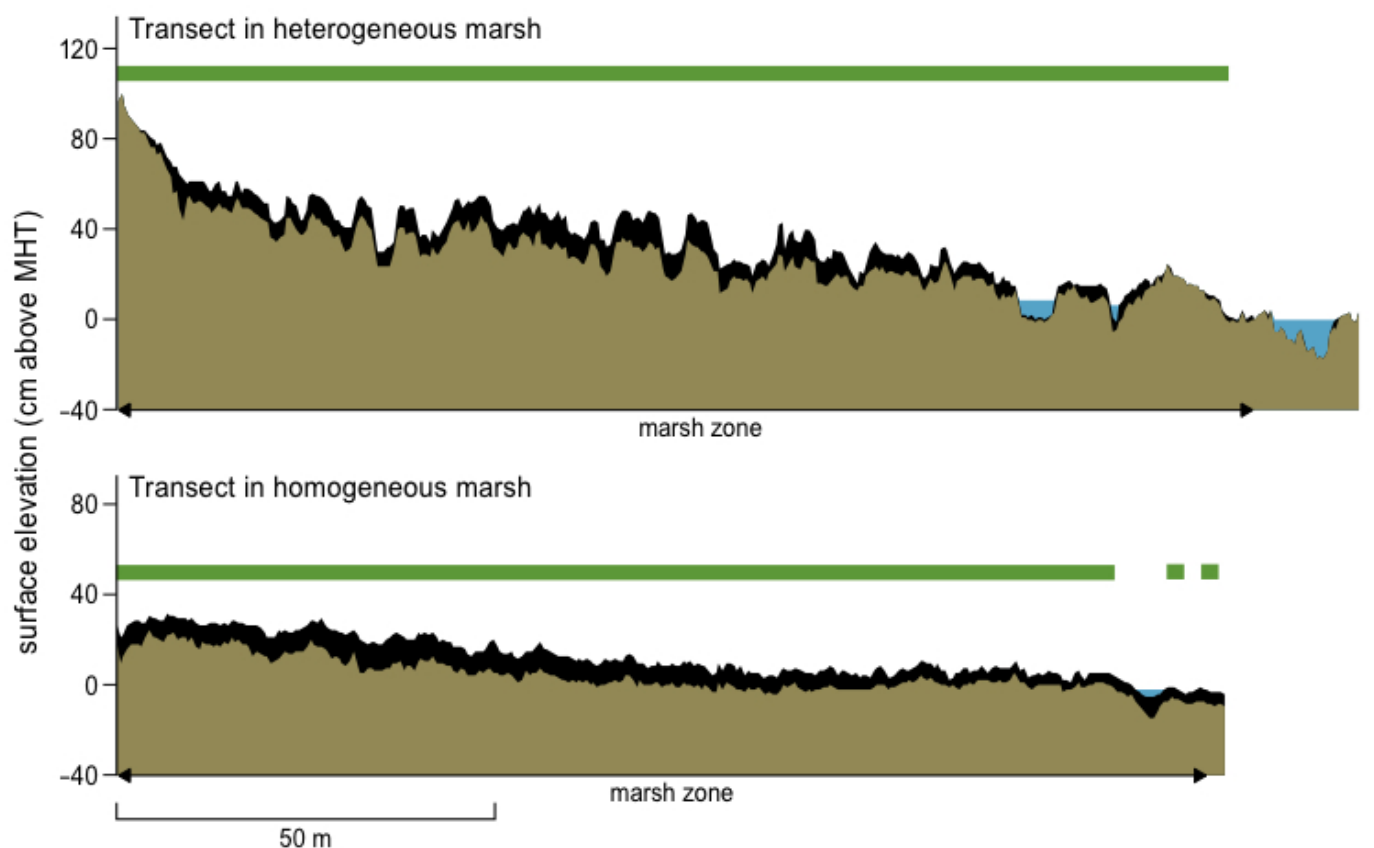

Figure 2. Transects on the Cefni marsh (a) and Schiermonnikoog (b). Light brown represents the coarse-grained sediment and dark brown represents the fine-grained sediment layer. When both hummocks and depressions were vegetated and had accumulated fine-grained sediment, we referred to it as the marsh zone. When vegetated hummocks were located on the bare intertidal flats, we referred to it as pioneer zone. 


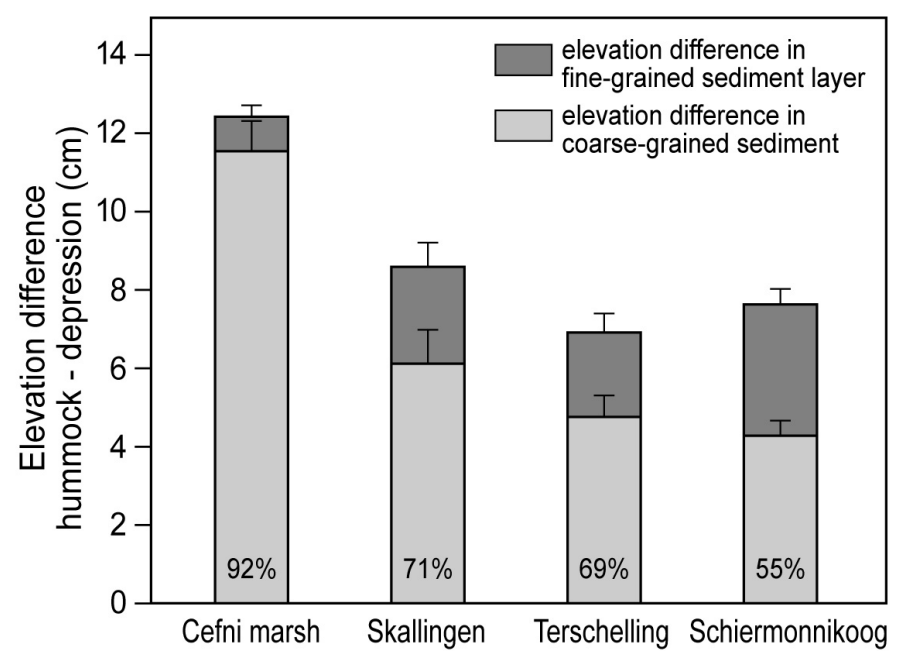

Figure 3. Elevational differences between hummocks and depressions estimated at four European sandy salt marshes. The elevational difference can arise from both heterogeneity of the underlying coarse-grained sediment and differences in thickness in the top fine-grained sediment layer. Percentages represent how much of the elevational difference, on average, were explained by the morphology of the coarse-grained sediment.

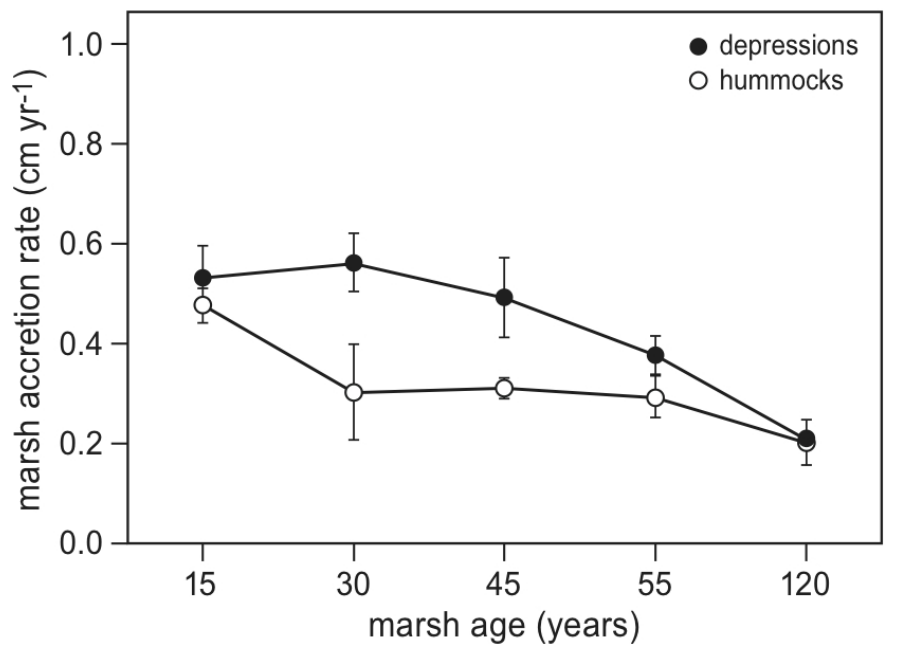

Figure 4. Marsh accretion rates $\left(\mathrm{cm} \cdot\right.$ year $\left.^{-1}\right)$ based on annual measurements between 2001 and 2011 on hummocks and depressions along the natural chronosequence of Schiermonnikoog.

\section{Discussion}

Our results support the first hypothesis that the patterns are formed on the intertidal flat before fine-grained sediment accumulated during marsh development. In all four salt marshes, more than $50 \%$ of the heterogeneity was explained by heterogeneity in the coarse-grained sediment (Figure 3). Furthermore, the transects measured at the Cefni marsh and on Schiermonnikoog also showed that the marsh platform followed the topography of the underlying coarse-grained substrate (Figure 2). Therefore, we conclude that the small-scale topographic heterogeneity was formed in the pioneer stage before the morphology of the intertidal flat was conserved under a layer of fine-grained sediment. We reject the second hypothesis that the patterns are formed after marsh development started. However, the topographic heterogeneity was enhanced during early marsh development, as we found a thicker fine-grained sediment layer on top of hummocks compared to the depressions in all four marshes (Figure 3). The marsh elevation determines for a large part whether salt-marsh plant species can 
successfully establish [26], and vegetation is known to increase the sediment deposition rate and reduce the erosion rate by stabilization of the soil [10-12]. Higher elevated hummocks covered by vegetation in the pioneer zone (see Figure 2, transects 1 and 2 in the pioneer zone in front of the marsh zone) will have a higher marsh accretion rate compared to the adjacent bare intertidal flat.

From the 15 year-old marsh up to the 120 year-old marsh, we found a significantly higher marsh accretion rate within the depressions (Figure 4). This higher accretion rate was mainly present in the intermediate marsh ages of 30 and 45 years old (Figure 4). This would result in dampening of the topographic heterogeneity over time. At the 55- and 120-year-old marshes, we actually found similar marsh accretion rates. All these results lead to the following conclusions: 1) heterogeneity in marsh topology was formed before the marsh developed; 2) during early marsh development, the vegetated hummocks accumulated more fine-grained sediments compared to the bare intertidal flat, which enhanced the elevational heterogeneity; 3) higher marsh accretion rates in the depressions caused the topographic heterogeneity to dampen; and 4) at mature marshes, similar marsh accretion rates between the hummocks and the depressions allowed for the patterns to persist in the marsh platform.

The persistence of small-scale topographic heterogeneity in marshes depends, for the large part, on the marsh accretion rate. The marshes included in this study were all sandy marshes with a thin fine-grained sediment layer on top of coarse-grained sediment and average marsh accretion rates of several $\mathrm{mm} \cdot$ year $^{-1}[23,27]$ depending on marsh elevation and marsh age [27]. Many mainland and estuarine marshes have very high accretion rates, up to $40 \mathrm{~mm} \cdot$ year $^{-1}$ [28-30]. In the literature, a few studies have addressed hummock formation in estuarine marshes $[19,31]$ and marshes located within a bay [17,32]. In these studies, hummock formation occurred by active sediment trapping driven by Puccinellia maritima [17,32] or Spartina anglica $[19,31]$. This is in line with the results that we found that the hummocks in the pioneer zone were dominated by Puccinellia maritima (Table 1). According to a previous study [33], Puccinellia maritima and Spartina anglica will outcompete each other for space and light within the pioneer zone, and these authors concluded that Puccinellia maritima will prevail in more sandy marshes, whereas Spartina anglica will prevail in more clayish marshes. Therefore, hummock formation in the pioneer zone occurred in both sandy marshes with low accretion rates as well as in more clayish marshes with high accretion rates and, depending on soil type, either Puccinellia maritima or Spartina anglica caused hummocks to form in the pioneer zone. However, with increasing time, Spartina anglica tended to form large monospecific stands on the clayish marshes, whereas on the more sandy marshes, smaller scattered hummocks dominated by Puccinellia maritima remain presently [33].

This study contributes to general knowledge on the formation of marsh morphology and how topographic heterogeneity in marshes forms. Environmental heterogeneity within ecosystems can be important to boost biodiversity, which is one of the key objectives in conservation ecology [2,34]. The presence of this small-scale topographic heterogeneity in heterogeneous salt marshes likely increases biodiversity, compared to homogeneous salt marshes, and this could benefit not only primary (plant diversity) but also secondary diversity (e.g., herbivores). Additionally, heterogeneity is known to increase the resilience of ecosystems to changing environmental conditions [4,5]. Tidal marshes are very dynamic ecosystems, where the interplay between vegetation and sedimentation determines not only how the morphology of the marsh platform develops but also have a major impact on many important ecosystem functions, such as carbon sequestration [35,36], coastal protection [37], and the ability of marshes to cope with enhanced sea-level rise [8]. Understanding the feedbacks between vegetation and sedimentation, and their impact on marsh morphology, therefore, is key in the successful conservation of our coastal ecosystems.

Acknowledgments: We would like to acknowledge Harm Albers, Jan-Eise Wieringa, Elske Koppenaal and the Coastal Ecology Expedition for help with fieldwork, Dick Visser for help preparing the graphs and two anonymous reviewers for very useful comments on this manuscript. Esther Chang edited the manuscript. Many people have, throughout the years, contributed to the data collection of the SEB data on Schiermonnikoog: Dries Kuijper, Yzaak de Vries, Wolfgang Qual, Bregje Wesenbeeck, Alma de Groot and Elske Koppenaal, with special thanks to Dries Kuijper for installing the SEBs and Alma de Groot for organizing the database. This study 
was funded by ZKO-NWO, project number 83908320, the Dutch Organization for Scientific Research as well as the Schure-Beijerinck-Popping Fund.

Author Contributions: Conceived and designed the study: K. Elschot and J.P. Bakker. Performed the study: K. Elschot. Collection of field data: K. Elschot. Analysed the data: K. Elschot. Wrote the paper: K. Elschot and J.P. Bakker.

Conflicts of Interest: The authors declare no conflict of interest.

\section{References}

1. Hooper, D.U.; Chapin, F.S.; Ewel, J.J.; Hector, A.; Inchausti, P.; Lavorel, S.; Lawton, J.H.; Lodge, D.M.; Loreau, S.; Naeem, S.; et al. Effects of biodiversity on ecosystem functioning: A consensus of current knowledge. Ecol. Monogr. 2005, 75, 3-35. [CrossRef]

2. Ricklefs, R.E. Environmental heterogeneity and plant species diversity: A hypothesis. Am. Nat. 1977, 111, 376-381. [CrossRef]

3. Costanza, J.K.; Moody, A.; Peet, R.K. Multi-scale environmental heterogeneity as a predictor of plant species richness. Landsc. Ecol. 2011, 26, 851-864. [CrossRef]

4. Snyder, R.E.; Chesson, P. How the spatial scales of dispersal, competition, and environmental heterogeneity interact to affect coexistence. Am. Nat. 2004, 164, 633-650. [CrossRef] [PubMed]

5. Godfree, R.; Lepschi, B.; Reside, A.; Bolgers, T.; Robertson, B.; Marshall, D.; Carnegie, M. Multiscale topoedaphic heterogeneity increases resilience and resistance of a dominant grassland species to extreme drought and climate change. Glob. Change Biol. 2011, 17, 943-958. [CrossRef]

6. Thomas, C.D.; Cameron, A.; Green, R.E.; Bakkenes, M.; Beaumont, L.J.; Collingham, Y.C.; Erasmus, B.F.N.; Ferreira de Siqueira, M.; Grainger, A.; Hannah, L.; et al. Extinction risk from climate change. Nature 2004, 427, 145-148. [CrossRef] [PubMed]

7. Fitzgerald, D.M.; Fenster, M.S.; Argow, B.A.; Buynevich, I.V. Coastal impacts due to sea-level rise. Annu. Rev. Earth Planet. Sci. 2008, 36, 601-647. [CrossRef]

8. Kirwan, M.L.; Guntenspergen, G.R.; D'Alpaos, A.; Morris, J.T.; Mudd, S.M.; Temmerman, S. Limits on the adaptability of coastal marshes to rising sea level. Geophys. Res. Lett. 2010, 37, L23401. [CrossRef]

9. Olff, H.; de Leeuw, J.; Bakker, J.P.; Platerink, R.J.; van Wijnen, H.J. Vegetation succession and herbivory in a salt marsh: Changes induced by sea level rise and silt deposition along an elevational gradient. J. Ecol. 1997, 85, 799-814. [CrossRef]

10. Peralta, G.; van Duren, L.A.; Morris, E.P.; Bouma, T.J. Consequences of shoot density and stiffness for ecosystem engineering by benthic macrophytes in flow dominated areas: A hydrodynamic flume study. Mar. Ecol. Progr. Ser. 2008, 368, 103-115. [CrossRef]

11. Mudd, S.M.; D'Alpaos, A.; Morris, J.T. How does vegetation affect sedimentation on tidal marshes? Investigating particle capture and hydrodynamic controls on biologically mediated sedimentation. J. Geophys. Res. 2010, 115, 1-14. [CrossRef]

12. Day, J.W.; Kemp, G.P.; Reed, D.J.; Cahoon, D.R.; Boumans, R.M.J.; Suhayda, J.M.; Gambrell, R. Vegetation death and rapid loss of surface elevation in two contrasting Mississippi delta salt marshes: The role of sedimentation, autocompaction and sea-level rise. Ecol. Eng. 2011, 37, 229-240. [CrossRef]

13. Temmerman, S.; Bouma, T.J.; van de Koppel, J.; van der Wal, D.; de Vries, M.B.; Herman, P.M.J. Vegetation causes channel erosion in a tidal landscape. Geology 2007, 35, 631-634. [CrossRef]

14. Fagherazzi, S.; Kirwan, M.L.; Mudd, S.M.; Guntenspergen, G.T.; Temmerman, S.; D'Alpaos, A.; van de Koppel, J.; Rybczyk, J.M.; Reyes, E.; Craft, C.; et al. Numerical models of salt marsh evolution: Ecological, geomorphic, and climatic factors. Rev. Geophys. 2012, 50, RG1002. [CrossRef]

15. Vandenbruwaene, W.; Bouma, T.J.; Meire, P.; Temmerman, S. Bio-geomorphic effects on tidal channel evolution: Impact of vegetation establishment and tidal prism change. Earth Surf. Process. Landf. 2013, 38, 122-132. [CrossRef]

16. Gray, A.J.; Bunce, R.G.H. The ecology of Morecambe Bay. VI. Soils and vegetation of the salt marshes: A multivariate approach. J. Appl. Ecol. 1972, 9, 221-234. [CrossRef]

17. Langlois, E.; Bonis, A.; Bouzillé, J.B. Sediment and plant dynamics in saltmarshes pioneer zone: Puccinellia maritima as a key species? Estuar. Coast. Shelf Sci. 2003, 56, 239-249. [CrossRef] 
18. Stribling, J.; Cornwell, J.; Glahn, O. Microtopography in tidal marshes: Ecosystem enginering by vegetation? Estuar. Coasts 2007, 30, 1007-1015. [CrossRef]

19. Balke, T.; Klaassen, P.C.; Garbutt, A.; van der Wal, D.; Herman, P.M.J.; Bouma, T.J. Conditional outcome of ecosystem engineering: A case study on tussocks of the salt marsh pioneer Spartina anglica. Geomorphology 2012, 153-154, 232-238. [CrossRef]

20. Oliver, F.W. The Bouche d'Erqui in 1907. New Phytol. 1907, 6, 244-252.

21. Yapp, R.H.; John, D.; Jones, O.T. The salt marshes of the Dovey Estuary. Part II. The salt marshes. J. Ecol. 1917, 5, 65-103. [CrossRef]

22. De Groot, A.V.; Veeneklaas, R.M.; Kuijper, D.P.J.; Bakker, J.P. Spatial patterns in accretion on barrier-island salt marshes. Geomorphology 2011, 134, 280-296. [CrossRef]

23. Packham, J.R.; Liddle, M.J. The Cefni salt marsh, Anglesey, and its recent development. Field Stud. 1970, 3 , 331-356.

24. Boumans, R.M.J.; Day, J.W. High precision measurements of sediment elevation in shallow coastal areas using a sedimentation-erosion table. Estuaries 1993, 16, 375-380. [CrossRef]

25. Nolte, S.; Koppenaal, E.C.; Esselink, P.; Dijkema, K.S.; Schuerch, M.; de Groot, A.V.; Bakker, J.P.; Temmerman, S. Measuring sedimentation in tidal marshes: A review on methods and their applicability in biogeomorphological studies. J. Coast. Conserv. 2013, 17, 301-325. [CrossRef]

26. Davy, A.J.; Brown, M.J.H.; Mossman, H.L.; Grant, A. Colonization of a newly developing salt marsh: Disentangling independent effects of elevation and redox potential on halophytes. J. Ecol. 2011, 99, 1350-1357. [CrossRef]

27. Van Wijnen, H.J.; Bakker, J.P. Nitrogen accumulation and plant species replacement in three salt marsh systems in the Wadden Sea. J. Coast. Conserv. 1997, 3, 19-26. [CrossRef]

28. Oenema, O.; Delaune, R.D. Accretion rates in salt marshes in the Eastern Scheldt, south-west Netherlands. Estuar. Coast. Shelf Sci. 1988, 26, 379-394. [CrossRef]

29. Dijkema, K.S.; Kers, A.S.; van Duin, W.E. Salt marshes: Applied long-term monitoring salt marshes. In Wadden Sea Ecosystem No. 26; Trilateral Monitoring and Assessment Group, Common Wadden Sea Secretariat: Wilhelmshaven, Germany, 2010; Volume 26, pp. 35-40.

30. Suchrow, S.; Pohlmann, N.; Stock, M.; Jensen, K. Long-term surface elevation changes in German North Sea salt marshes. Estuar. Coast. Shelf Sci. 2012, 98, 71-83. [CrossRef]

31. Van Wesenbeeck, B.K.; van de Koppel, J.; Herman, P.M.J.; Bouma, T.J. Does scale-dependent feedback explain spatial complexity in salt-marsh ecosystems? Oikos 2008, 117, 152-159. [CrossRef]

32. Langlois, E.; Bonis, A.; Bouzillé, J.B. The response of Puccinellia maritima to burial: A key to understanding its role in salt-marsh dynamics? J. Veg. Sci. 2001, 12, 289-297. [CrossRef]

33. Scholten, M.; Rozema, J. The competitive ability of Spartina anglica on Dutch salt marshes. In Spartina Anglica, a Research Review; Gray, A.J., Benham, P.E.M., Eds.; Institute of Terrestrial Ecology: London, UK, 1990; pp. 39-47.

34. Stein, A.; Gerstner, K.; Kreft, H. Environmental heterogeneity as a universal driver of species richness across taxa, biomes and spatial scales. Ecol. Lett. 2014, 17, 866-880. [CrossRef] [PubMed]

35. Mcleod, E.; Chmura, G.L.; Bouillon, S.; Salm, R.; Björk, M.; Duarte, C.M.; Lovelock, C.E.; Schlesinger, W.H.; Silliman, B.R. A blueprint for blue carbon: Toward an improved understanding of the role of vegetated coastal habitats in sequestering CO2. Front. Ecol. Environ. 2011, 9, 552-560. [CrossRef]

36. Elschot, K.; Bakker, J.P.; Temmerman, S.; van de Koppel, J.; Bouma, T.J. Ecosystem engineering by large grazers enhances carbon stocks in a tidal salt marsh. Mar. Ecol. Progr. Ser. 2015, 537, 9-21. [CrossRef]

37. Gedan, K.B.; Kirwan, M.L.; Wolanski, E.; Barbier, E.B.; Silliman, B.R. The present and future role of coastal wetland vegetation in protecting shorelines: Answering recent challenges to the paradigm. Clim. Change 2011, 106, 7-29. [CrossRef]

(c) 2016 by the authors; licensee MDPI, Basel, Switzerland. This article is an open access article distributed under the terms and conditions of the Creative Commons by Attribution (CC-BY) license (http:/ / creativecommons.org/licenses/by/4.0/). 